\title{
Probiotic Endophytes for More Sustainable Banana Production
}

\author{
Miguel J. Beltran-Garcia 1,2,*, America Martinez-Rodriguez 2,3, Ileana Olmos-Arriaga 2,3, \\ Benjamin Valdez-Salas ${ }^{3}\left(\mathbb{D}\right.$, Yur Y. Chavez-Castrillon ${ }^{1}$, Paolo Di Mascio ${ }^{4, *}$ and James F. White ${ }^{5, * \mathbb{D}}$ \\ 1 Lab 309-E Building, Chemistry Department, Universidad Autonoma de Guadalajara, \\ Zapopan 45129, Jalisco, Mexico; veki.123@hotmail.com \\ 2 Departamento de Biotecnologicas y Ambientales, Universidad Autonoma de Guadalajara, \\ Zapopan 45129, Jalisco, Mexico; america.mr88@hotmail.com (A.M.-R.); ileanaolmos98@gmail.com (I.O.-A.) \\ 3 Engineering Institute, Universidad Autónoma de Baja California, Mexicali 21280, Baja California, Mexico; \\ benval@uabc.edu.mx \\ 4 Department of Biochemistry, Institute of Chemistry, University of São Paulo, São Paulo 05508-000, SP, Brazil \\ 5 Department of Plant Biology, Rutgers University, New Brunswick, NJ 08901, USA \\ * Correspondence: mbeltran71@hotmail.com (M.J.B.-G.); pdmascio@iq.usp.br (P.D.M.); \\ jwhite3728@gmail.com (J.F.W.)
}

check for

updates

Citation: Beltran-Garcia, M.J.;

Martinez-Rodriguez, A.;

Olmos-Arriaga, I.; Valdez-Salas, B.;

Chavez-Castrillon, Y.Y.; Di Mascio, P.;

White, J.F. Probiotic Endophytes for

More Sustainable Banana Production.

Microorganisms 2021, 9, 1805.

https://doi.org/10.3390/

microorganisms 9091805

Academic Editor: Renato Fani

Received: 1 August 2021

Accepted: 18 August 2021

Published: 25 August 2021

Publisher's Note: MDPI stays neutral with regard to jurisdictional claims in published maps and institutional affiliations.

\begin{abstract}
Climatic factors and pathogenic fungi threaten global banana production. Moreover, bananas are being cultivated using excessive amendments of nitrogen and pesticides, which shift the microbial diversity in plants and soil. Advances in high-throughput sequencing (HTS) technologies and culture-dependent methods have provided valuable information about microbial diversity and functionality of plant-associated endophytic communities. Under stressful (biotic or abiotic) conditions, plants can recruit sets of microorganisms to alleviate specific potentially detrimental effects, a phenomenon known as "cry for help". This mechanism is likely initiated in banana plants infected by Fusarium wilt pathogen. Recently, reports demonstrated the synergistic and cumulative effects of synthetic microbial communities (SynComs) on naturally occurring plant microbiomes. Indeed, probiotic SynComs have been shown to increase plant resilience against biotic and abiotic stresses and promote growth. This review focuses on endophytic bacterial diversity and keystone taxa of banana plants. We also discuss the prospects of creating SynComs composed of endophytic bacteria that could enhance the production and sustainability of Cavendish bananas (Musa acuminata AAA), the fourth most important crop for maintaining global food security.
\end{abstract}

Keywords: Banana; Bacillus; Cavendish; Chryseobacterium; Endophytic bacteria; Enterobacter; Fusarium oxysporum; Probiotics; Pseudocercospora fijiensis; Pseudomonas; Sigatoka; SynComs

\section{Introduction}

In 2017, bananas were ranked 12th among the top 20 commodities globally, reaching a record production of 116 million tons. Currently, around 5.2 million hectares in 135 countries are dedicated to banana production [1]. Additionally, banana is the fourth most important crop, often recognized as a staple in food security and cash crop for generating income [2]. The most common and widely exported banana is the Cavendish (AAA) group of dessert bananas (Lacatan, Robusta, Valery, Giant Cavendish, Grand Naine, dwarf Cavendish, Petit Naine, and dwarf Parfitt) that account for about $43 \%$ of global banana production [1].

Cavendish bananas are grown in nutrient-limited soils under excessive nitrogen (N) fertilization and frequently water-limited conditions [3,4]. In addition, pathogenic fungi, which are becoming increasingly virulent and resistant to fungicides, threaten banana production in major growing areas [4-7]. Banana plants have a relatively high nutrient and water demand compared to other crops; therefore, applications of high dosages of potassium (K) and $\mathrm{N}$ are required in banana orchards to replenish the nutrients exported from the soil to the plant and fruits [8]. It has been reported that an average of 
$400 \mathrm{Kg} \mathrm{N} \mathrm{ha}^{-1} \mathrm{Y}^{-1}$ is used in the Caribbean and Latin American banana orchards, resulting in severe contamination of water bodies [9].

Due to food safety and sustainable agricultural management concerns, banana production is transitioning from conventional crop management approaches to certified and high-yielding organic systems, including microbial inoculants. However, despite the solid global trend to cultivate crops under organic management, few inoculants on the market replace chemical agents. The vast majority of commercial products are composed of Pseudomonas and Bacillus strains [10]. These observations emphasize the urgent need to develop new technologies based on plant-growth-promoting bacteria (PGPB) as microbial inoculants [11]. Interestingly, plant-beneficial bacteria living in soil as free organisms or as endophytes can trigger plant growth and protect plants from disease and abiotic factors through a wide variety of mechanisms $[12,13]$. Thus, promoting the propagation of these bacteria represents a potential approach for improving banana production and sustainability organically.

Endophytic bacteria reside in the internal tissues of the plant, establishing a strong symbiotic relationship that promotes plant growth and provides protection in exchange for a niche to carry out its life cycle [14]. The nature of their mutualistic association depends on their location in the plant tissue, either intercellularly or intracellularly [15,16]. Since they promote plant growth, increase crop yields, and afford disease resistance under harsh environmental conditions, endophytic bacteria are considered plant probiotics [17-21].

This review highlights the interest in probiotic banana endophytes as a new generation of microbial inoculants for organic banana production. We also discuss how endophytic bacterial diversity is shifted under abiotic or biotic stress conditions. Undoubtedly, understanding such changes will provide clues about which endophytic bacteria could be components of novel microbial inoculant formulas for managing specific crops. Furthermore, we describe the concept of synthetic communities (SynComs) containing keystone taxa that can support sustainable banana production.

\section{Plant Microbiomes: The Origin of Plant Probiotic Bacteria}

Plants have distinct microenvironments that harbor complex and diverse microbial communities, considered a second genome [22]. Plants have selected these microbial communities over millions of years of co-evolution to form a plant-specific microbiome, resulting in various interactions between plants and microorganisms [23]. Additionally, beneficial and detrimental microbial effects on plants can directly or indirectly affect microorganism-microorganism interactions [24].

Beneficial microbes (i.e., rhizospheric and endophytic) improve the acquisition of soil nutrients and tolerance to abiotic stresses and combat pathogens. These functions promote plant growth and consequently increase the ecological fitness of the natural environmental or agricultural system [25]. Endophytic microbes are a subset of the plant microbiome. This group of diverse and heterogeneous bacteria can easily enter plant roots through different mechanisms [26]. It is important to point out that the nature of plant-endophyte interactions can range from mutualism to pathogenicity. It was previously demonstrated that the type of interaction depends on abiotic and biotic factors, including the genotypes of plants and microbes, environmental conditions, and the dynamic networks of interactions within plant biomes [27].

Investigating the diversity and structure of a plant microbiome provides information about microbial diversity and sheds light on the function of endophytic bacteria in their plant host. Hardoim et al. [27] and Santoyo et al. [28] identified an endophytic plant microbiome composed of 21 bacterial phyla with two from Archaea. Moreover, four of the phyla, previously reported in soils and epiphytic-associated environments [29], accounted for $96 \%$ of the total endophyte microbiome. The most representative phyla of bacterial endophytes include Proteobacteria with $54 \%$ (including $\alpha, \beta$, and $\gamma$ classes), Actinobacteria (20\%), Firmicutes (16\%), and Bacteroidetes (6\%) [27]. However, many endophytes are not culturable $[30,31]$. In this sense, culturable and non-culturable microbial 
analyses are required to comprehensively unravel the banana-endophytic community interactions [32-34].

More recently, microbiologists have been using high-throughput sequencing (HTS) methods to explore the structure of bacterial communities, identifying members that cannot be easily cultured in the laboratory [35-37], including phyla such as Planctomycetes, Verrucomicrobia, and Acidobacteria [38,39]. A significant proportion of the bacterial genera reported as endophytic is commonly found in the rhizosphere, suggesting that the endophytic microbiome may be a subpopulation of the rhizospheric bacteria [14].

It has been proposed that endophytic bacteria could be used as "plant probiotics" for microbiome reconstruction, improving crop yields, and reducing or even eliminating the requirement for chemical fertilizers [40-42]. Additionally, cultured bacterial endophytes display plant growth-promoting (PGP) traits, including nitrogen fixation, nutrient (e.g., nitrogen, phosphate, zinc, and other nutrient elements) and water uptake, and essential phytohormone production (e.g., indole acetic acid (IAA), cytokinin and abscisic acid) $[43,44]$. These bacteria indirectly provide plants with resistance or tolerance to biotic and abiotic stresses [45-47] by upregulating ACC deaminase activity and modulating ethylene biosynthesis [48].

Many PGP endophytic microbes are widely accepted as biofertilizers, biostimulants, and biocontrol agents $[11,13,49]$. These microbes exert antagonistic effects by producing antibiotic compounds, lipopeptides, cell wall degrading enzymes, volatile compounds, hydrogen cyanide $(\mathrm{HCN})$, and siderophores [50-53]. Some of these beneficial microbes aggregate the soil particles to improve the soil structure and secrete extracellular metabolites to augment the breakdown of complex organic material and insoluble nutrients into simple, more available forms [54].

\section{Synthetic Communities as Probiotic Bioinoculants}

In recent years, significant steps have been taken towards understanding many facets of the plant microbiome and their interactions. With advances in sequencing technologies and analytical tools, we have learned about plant-microbial and microbial-microbial interactions and how microbes are recruited from the environment and assembled into a defined structure. These interactions are widely dependent on soil type, host genotype, and agricultural management [55]. Indeed, these types of studies have altered our perception of the complexity and dynamics of plant-microbe interactions.

Plant microbiomes have been studied by inferred functions derived from descriptive genetic data (metagenomics) and/or combined with metabolomics and culture-dependent approaches to develop synthetic microbial communities (SynComs) [56-58]. SynCom research and development involves employing microbial candidates as new functional probiotics for plants [57,59]. According to an analysis of 30 publications, Marin et al. [60] showed that SynComs could range from 3 to 190 microbial strains, mainly composed of bacteria belonging to the phyla Proteobacteria, Actinobacteria, Firmicutes, and Bacteriodetes.

After assembling the microbial consortium, it is then tested in plants to evaluate whether the functions and structure mimic the observed function and structure of the plant microbiome under natural conditions in the time and space of a multidimensional and complex system $[55,60]$. This approach reduces the complexity of the microbial community without modifying the original interactions among microbes and the host plant (Reviewed in $[59,60])$. A significant advantage of SynComs is that they are composed of adapting microbial communities with defined and predictable traits for crop management, producing effects that a single microbe could not generate. Additionally, due to the plasticity of SynComs in the laboratory, it is possible to understand how the plant alters its behaviors and genetic responses by removing one or several members of the consortium [60].

Plant microbiome studies are gradually considering the synergistic and cumulative effects of SynComs on different microorganisms, expanding our knowledge of plant diseases [61-67]. SynComs have also been designed to elucidate the specific function of plant microorganisms, including nutritional aspects (e.g., nitrogen fixation by diazotrophs) [68] 
and mineral assimilation (e.g., phosphate and organic nitrogen) [69,70]. Thus, the concept of SynComs for creating microbial consortia under laboratory conditions is a promising ecological strategy for developing more resilient and productive crops.

\section{The Banana Endophytic Microbiome or Endophytome: History, Diversity, Functionality, and the Cry for Help Phenomena}

According to the Scopus and Pubmed databases, as of 15 July 2021, more than 115 articles have been published on the functional properties and uses of microbial endophytes (including fungi) isolated from banana plants. We used different combinations of the search terms "banana" and "endophyte" and combinations of the following six terms: 1. Biological control, 2. Fusarium wilt, 3. Community diversity, 4. Plant-growth promoting traits and PGPR, 5. Endosphere, and 6. Keystone taxa. We found that biological control and Fusarium wilt were the most reported topics published. Many articles retrieved using these combinations were present in both databases. This observation suggests there is little information about the use of banana endophytic bacteria as probiotics or bioinoculants.

\subsection{Pioneer Studies of Banana Endophyte}

The earliest published works highlighted the antifungal, nematicide activities of reintroduced endophytic fungi from banana leaves and roots [71-73]. On the other hand, Esperanza Martinez-Romero and collaborators [74] published one of the first reports of endophytic diazotrophic bacterial strains, including Enterobacter cloacae, Pantoea agglomerans, Klebsiella pneumoniae, K. oxytoca, and Rhizobium undicola, isolated from a commercial banana plantation in Mexico. Later, Cao et al. [75] showed that the siderophore-producing Streptomyces could be used as a biological control agent against the causative fungus of Fusarium wilt disease.

Pious Thomas in India contributed substantially to research on endophytic bacteria in Cavendish bananas (Grand Naine, Dwarf cavendish). His group was among the first to combine culture- and molecular-based methods with banana tissues obtained from commercial and micropropagated material in their laboratory. He and his co-workers remarked that many bacterial endophytes remain in a viable but not cultivable (quiescent) state in micropropagated plants but can be activated after several passages (at least 20), yielding different organisms $[30,31,76,77]$. In addition, they proposed an approach for determining the composition of the banana microbiome, which establishes the relationships of functional diversity in the plant. In addition, their work provided exciting information about the translation of research findings from the laboratory to the agricultural field with endophytic $P$. aeruginosa from banana plants. Finally, the authors highlighted the necessity of several studies to ensure the feasibility of introducing endophytes as functional inoculants [78].

Since those pioneering studies, the search for endophytic bacteria and fungi in bananas that can be cultured for biological solutions to control crop diseases, especially those caused by fungus, has intensified. The soil-borne Fusarium oxysporum $\mathrm{f}$. sp. cubense race 4 causes Panama disease [6], and Pseudocerospora fijiensis (previously Mycosphaerella fijiensis) is responsible for black Sigatoka disease [79]. Both fungal diseases are considered limiting factors for banana production worldwide.

\subsection{The Banana Bacterial Endophytome}

Recently, Nakeeran et al. [80] and Cabanás et al. [33] coined the term "banana endophytome." That term includes all inhabiting endophytic microorganisms with a potential role as a biostimulant or biocontrol agent against pests in banana plants. Herein, we will focus on studies that have evaluated endophyte bacterial diversity in the tissues of different banana varieties. We intend to use this information to create a synopsis of the diversity and functionality of bacteria and their phyla in banana plants.

Figure 1 summarizes the symbiotic traits of endophytic plant bacteria. Some of their properties are widely recognized in bacteria isolated from the banana endosphere. These traits include producing growth-regulating phytohormones and acquiring nutrients for 
plant growth. In addition, the response to biotic stress by inducing defense mechanisms produces antifungal and nematocidal compounds and supports tolerance to various types of abiotic stress.

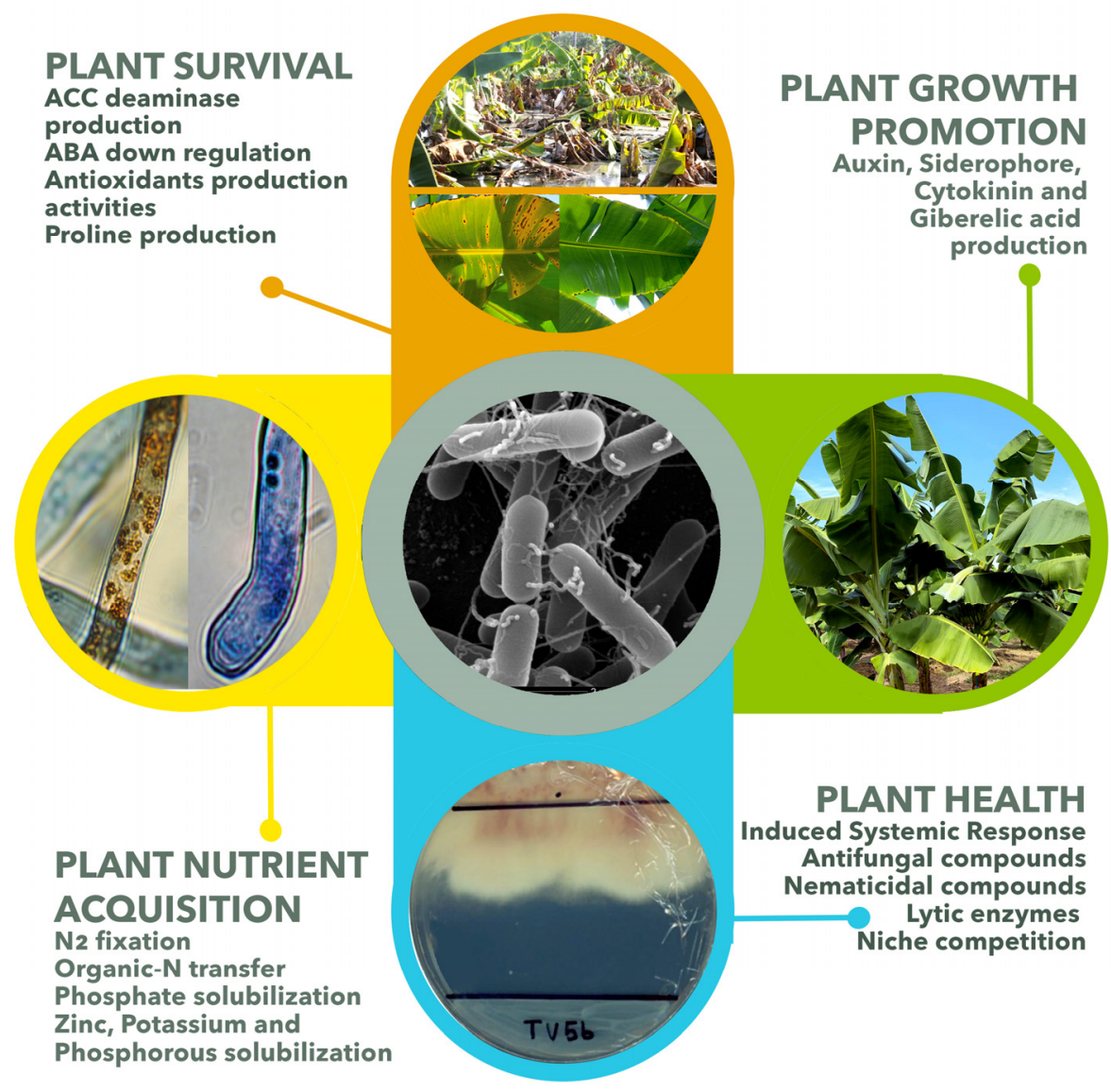

Figure 1. Symbiotic services/functions provided by endophytic probiotic bacteria. Endophyte bacteria can stimulate plant nutrient acquisition and health through different mechanisms and increase plant growth and production.

The endophytic bacteria of banana plants have been grouped into four major phyla: Proteobacteria, Firmicutes, Actinobacteria, Bacteroidetes, and other minor phyla such as Cyanobacteria, Chloroflexi, Verrucomicrobia, Planctomycetes, Acidobacteria, and Spirochaetes have been reported $[31,33,81]$. The $\gamma$-Proteobacteria is the most diverse and dominant. The most commonly isolated bacterial genera from Cavendish banana include Bacillus (Firmicutes), Pseudomonas ( $\gamma$-Proteobacteria), Klebsiella ( $\gamma$-Proteobacteria), Enterobacter $(\gamma$ Proteobacteria), Rhizobium ( $\alpha$-Proteobacteria), Staphylococcus (Firmicutes). Cumulatively, the evidence indicates that Bacillus and Pseudomonas are the most predominant genera in banana plants.

The diversity of endophytic bacterial in banana plants varies depending on the cultivar and the climatic, soil, and stress conditions. Moreover, the methods employed to quantitate these populations can influence the results and subsequent interpretation(s). For example, Rossmann et al. [82], using single-stranded conformational polymorphism (SSCP) and quantitative PCR (qPCR), reported that the pseudostem is an extraordinary microhabitat with the highest counts of endophytic bacteria (109 16SrRNA CFU gfw-1) in Musa sp., strain AAA EAHB (The East African Highland Cultivar group) in Uganda. Members of Enterobacteriaceae ( $\gamma$-Proteobacteria) were identified as significant components in the bacterial community. The authors found that Enterobacter (44.6\%) was predominant in plant-associated habitats, and Pantoea was predominant in soil (23.5\%). However, in the endosphere, these values differed compared to the rhizosphere and soil. As endo- 
phytes, Enterobacter (31.9\%), Pantoea (14\%), Raoultella (12.3\%), Klebsiella (11.4\%), and Serratia (11.35) are considered important genera for colonizing the pseudostem. However, the most isolated genus was Pseudomonas. Additionally, molecular fingerprinting analyses identified dominant bands associated with Flavobacteria, Sphingobacteria, Brevundimonas, Delftia, Herbaspirillum, Azoarcus, Acidovorax, and Diaphorobacter. Undoubtedly, the predominance of Enterobacteriaceae in the endosphere is due to fertilization with animal manure in these fields. It has been reported that bananas and other plants recruit this class of bacteria from the soil for its nitrogen-fixing and antifungal properties $[18,43,63,65]$. On the other hand, the high presence of Pseudomonas is likely due to the crop proximity to Fusarium wilt-infested fields. In Uganda, this disease has been incredibly destructive for banana plants.

In another study conducted in Africa (Kenya), Ngamau et al. [83] isolated and identified endophytic bacteria from Musa AAA-Cavendish and Musa AAB plantain bananas. The authors selected 214 isolates and grouped them into one of three families: Bacillaceae, Pseudomonadaceae, and Enterobacteriaceae. According to the 16S rRNA gene results, the Enterobacteriaceae family was the most diverse with eight genera: Serratia, Rahnella, Enterobacter, Yokenella, Raoultella, Klebsiella, Yersinia, and Ewingella. Both the Pseudomonadaceae and Bacillaceae families were represented by only one genus Pseudomonas and Bacillus. Interestingly, $100 \%$ of the bacterial isolates could fix nitrogen, $62 \%$ exhibited phosphate solubilization activity, and 12 Pseudomonas isolates displayed siderophore production. Notably, that microbial community matched with the ongoing decline in soil fertility in Kenya. However, these results contrast with those obtained by Brazilians evaluating bacterial populations in Prata Anã (AAB) bananas.

Souza et al. [84] and Andrade et al. [85] reported that the predominant phyla in Prata Anã (AAB) roots consisted of 70\% Firmicutes and 30\% Proteobacteria. Further analyses revealed that the isolates were from 15 species belonging to ten genera: Agrobacterium, Aneurinibacillus, Bacillus, Enterobacter, Klebsiella, Lysinibacillus, Micrococcus, Paenibacillus, Rhizobium, and Sporolactobacillus. The genus Bacillus was the most frequently identified (87.3\%), followed by Lysinibacillus (3.9\%).

Pereira et al. [86], from the same research group in Brazil, characterized 39 bacterial isolates from roots and grouped them into 4 genera: Bacillus, Rhizobium, Klebsiella, and Enterobacter. The genus Bacillus occurred more frequently $(92.5 \%)$ than the other genera, which only contained one representative of each genus (2-5\%). The identified Bacillus species included: B. subtilis (as the most predominant species), B. pumilus, B. safensis, B. altitudinis, $B$. thuringiensis, B. cereus, B. amyloliquefaciens, B. axarquienses, and B. megaterium. None of the identified isolates, including the Rhizobium strain, could fix atmospheric nitrogen.

The cultivar Prata Anã is grown in a semi-arid environment in Brazil and has a narrow association with non-diazotrophic bacteria. However, $90 \%$ of the bacterial isolates were capable of reducing nitrate to nitrite. Nitrate reductase catalyzes the first step in the reduction of nitrate to ammonium for the N-organic synthesis. In addition, only $30 \%$ of the isolates were verified as urease positive, including Bacillus, Klebsiella and Enterobacter [86]. It is well-known that urease catalyzes the hydrolysis of urea to ammonium and $\mathrm{CO}_{2}$. Although the bacteria are non-diazotrophic, the enzymatic ammonium production and its subsequent transformation to organic nitrogen are sufficient for maintaining plant growth under nitrogen-deficient conditions, as demonstrated in other plant-endophyte systems [17]. Therefore, the abundance of Firmicutes in the Prata Anã roots with these enzymatic capabilities is strategic to survive naturally in a semi-arid environment and determines the use of mineral nitrates as fertilizer.

Using culture-dependent and culture-independent methods, Thomas and Sekhar [81] revealed differences in bacterial diversity of typically unculturable bacteria prevailing in sucker shoot-tips of Grand Naine cultivar (cv.) bananas compared to the culturable bacteria. In that study, the cultivable bacteria included 37 strains, including 16 genera and 24 species distributed almost equally among three phyla: Actinobacteria (36.1\%), 
Proteobacteria (33.3\%) and Firmicutes (30.6\%). Klebsiella pneumoniae, and K. oxytoca were the most common species.

Furthermore, a metagenomic method reported enormous bacterial diversity in banana plants. In one study, Proteobacteria was the dominant group (64\%), followed by Firmicutes (12.1\%), Actinobacteria (9.5\%), Bacteroidetes (6.4\%), Planctomycetes and Cyanobacteria and others $(>1 \%)$ contributing 14 phyla such as Acidobacteria and Verrucomicrobia and the domain Euryarcheota. Class distribution of the OTU (\%) values showed that the bacterial community consisted of $\gamma$-Proteobacteria (42.6\%), $\alpha$-Proteobacteria (14\%), Actinobacteria (9.01\%), Clostridia (6.5\%), $\beta$-Proteobacteria (6\%), and Bacilli (5.6\%) [81]. It is important to point out that the $\gamma$-Proteobacteria included agriculturally important genera such as Acinetobacter, Acetobacter, Klebsiella, Pseudomonas, Stenotrophomonas and Serratia.

Marcano et al. [87] published a study on endophytic bacteria associated with the roots of Cavendish banana plants under organic management in the Dominican Republic. They highlighted the presence of a Pseudomonas plecoglossicida strain that improved fruit yield and controlled black Sigatoka outbreaks. The 114 isolates belonged to 20 different genera, predominantly Bacillus, Pseudomonas, Enterobacter, and Stenotrophomonas. Bacteria from the genera Acinetobacter, Pantoea, Citrobacter, Lysinibacillus, Pseudoxanthomonas, Comamonas, and Rhizobium and others were considered minor genera. At the phylum level, it was found that banana roots contain 63\% Proteobacteria $(\alpha-, \beta$ - and $\gamma$-Proteobacteria) and $37 \%$ Firmicutes (only Bacillus and Lysinibacillus). The application of some of these endophytes was shown to reduce black Sigatoka disease severity in organic plantations in Colombia.

Cultivated endophytic bacteria isolated from leaves of a red banana variety (M. acuminata AAA, red Dacca) were grouped into three phyla: Actinobacteria, Proteobacteria, and Firmicutes, comprising 8 genera and 10 species. Most of the isolates belonged to Firmicutes $(40.7 \%)$, followed by Proteobacteria (41.11\%) and Actinobacteria (11.76\%). Moreover, the dominant bacterial genera in the red banana included Bacillus (36.97\%) and Klebsiella $(29.41 \%)$ [88].

Cabanás et al. [33] studied the structure, composition, and co-occurrence relationships of dwarf Cavendish banana root endophytome in mother plants and suckers in banana plantations in the Canary Islands. They collected >1000 culturable root endophytes. Culturable and non-culturable (i.e., HTS) approaches have indicated low microbial diversity within the banana root endosphere. According to their metagenomic results, Proteobacteria was the predominant phylum (72.3\%), followed by Actinobacteria (12.1\%) and Firmicutes $(1.3 \%)$. Furthermore, based on the co-occurrence network analyses, Pseudomonas was the dominant genus, playing a vital role in the endophytic root microbiome.

The dwarf Cavendish banana plant root endosphere core bacteriome was shown to be composed of few genera, with $41 \%$ of the total sequences distributed among Pseudomonas $(27 \%)$, Rhizobium (8\%), and Streptomyces (6\%). Proteobacteria, Bacteroidetes, and Actinobacteria were among the most dominant cultivable bacteria. Additionally, the genus Enterobacter was the fifth most abundant.

These studies demonstrate that the method of analysis, cultivar, and microhabitat (root, pseudostem, and leaf) are influential factors for endophytic bacteria diversity in banana plants. Figure 2 shows the relative abundance of endophytic bacteria that have been reported in some studies mentioned in this review. The studies were carried out in different tissues of banana plants (Dwarf Cavendish and red banana AAA) and Prata Anã (AAB) varieties grown in commercial plantations exposed to different stress factors (2A). We can also observe the influence of the analysis method (cultivated and non-cultivated) on the distribution of the endophytic microbial community (2B). 


\section{A}

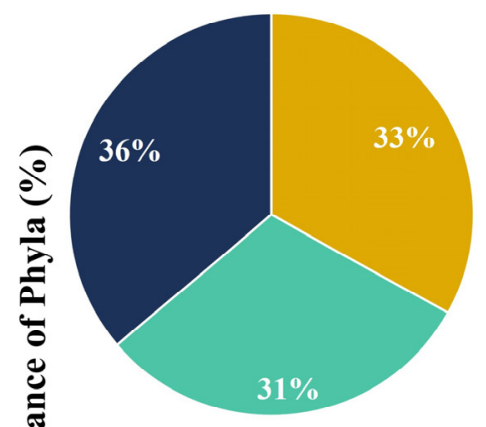

Grand Naine [81]

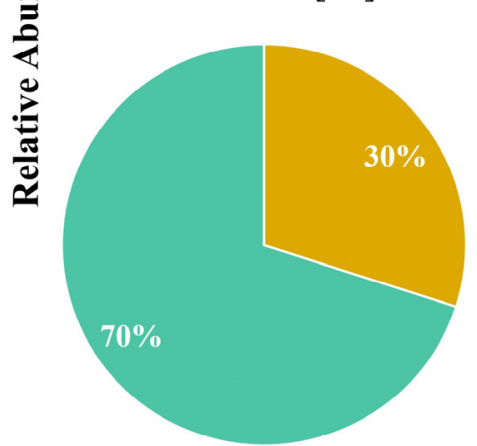

Prata Anã [84-86]

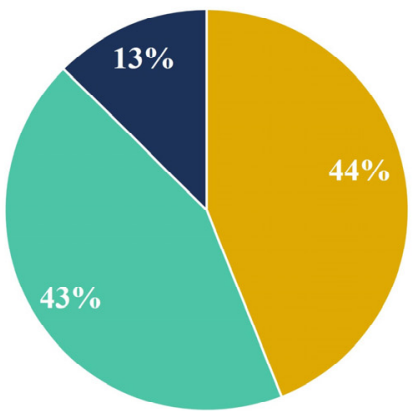

Red Banana [88]

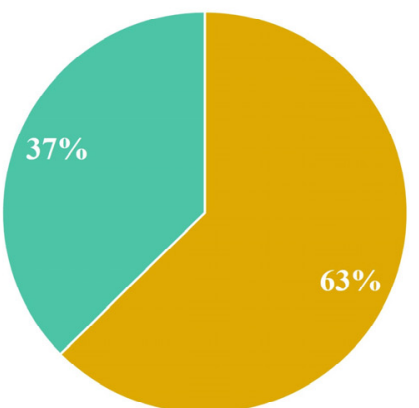

Grand Naine [87]

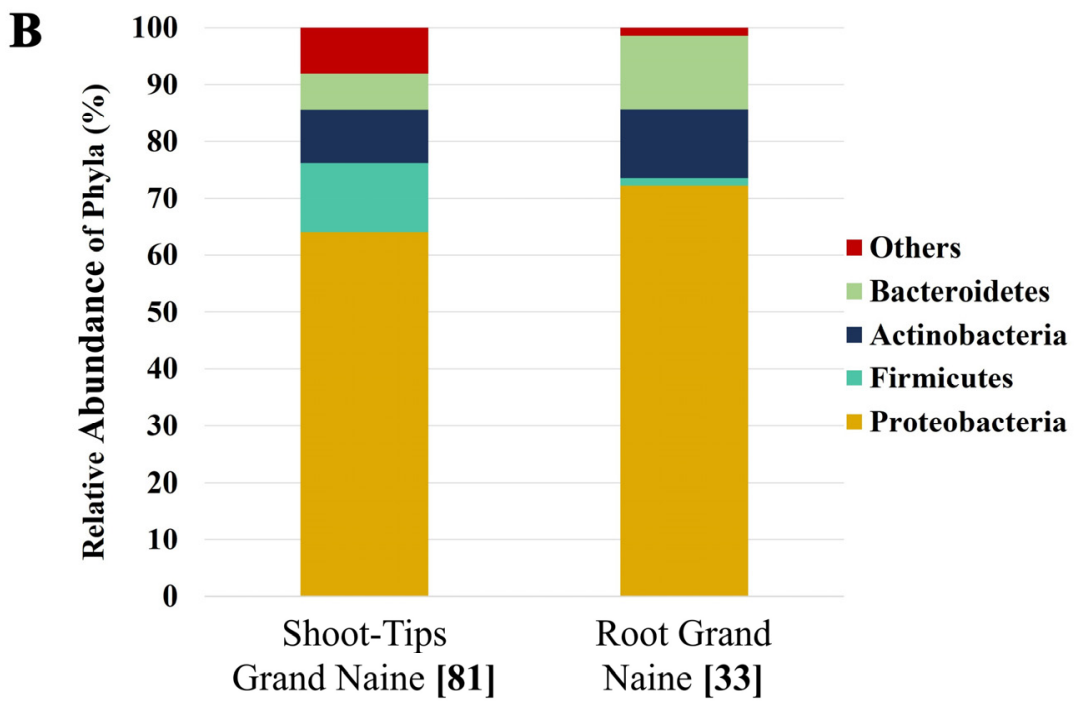

Figure 2. Relative abundance of cultivable and non-cultivable endophytic bacteria at phylum level from different cultivars of banana. (A) Comparative analysis among cultivable endophyte populations of shoot tips [81], roots under organic management [87], and red banana leaves of banana Cavendish AAA [87] and the Grand Naine under organic management. In the three tissues, the Proteobacteria was the predominant phylum. Leaves lacked members of the Actinobacteria phylum. Interestingly, Prata Anã recruits more Firmicutes to the roots. (B) Non-cultivable analysis of root endophytes. Both studies showed that Proteobacteria is the main microbial phylum in Cavendish bananas. The averages were calculated using data from previously published studies [33,81,84-88].

It is important to note that all published works about the diversity of banana endophytes have contributed to the knowledge of bacterial diversity and will help discover endophytic bacteria that could be candidate members of probiotic SymComs for banana cultivation. Additionally, our literature review revealed that combining culturable and non-culturable approaches facilitates the visualization of essential plant microorganisms or "keystone taxa." Keystone species play a significant role in shaping functional micro- 
bial networks, and their loss compromises the microbiome stability and the services they offer to plants $[89,90]$. Next-generation sequencing (NGS) studies have suggested that complex plant-microbe networks cope efficiently with environmental stresses, including those caused by pathogens. As we will discuss later, and based on the functionality of endophytic strains, various authors have suggested that Pseudomonas, Klebsiella, Enterobacter, Paenibacillus, Sphingophix, Micrococcus, and Rhizobium are keystone bacteria for banana plants $[18,33,91]$. For more information about keystone taxa, we direct the reader to the following publications [92-95].

\subsection{Fusarium Wilt Disease Shifts Endophytic Communities in Banana Plants}

Before introducing how biotic stress caused by Fusarium wilt disease alters the diversity of endophytic bacteria in bananas, it is important to note that plants under biotic and abiotic stress elicit a "cry for help" response mechanism to recruit both beneficial soil and rhizosphere microorganisms [96]. Plants adjusting their root exudate composition, mainly organic acids such as malate and oxalate, can replace inorganic phosphate $\left(\mathrm{P}_{\mathrm{i}}\right)$ bound in insoluble $\mathrm{P}_{\mathrm{i}}$-complexes via metal ion chelation or anion exchange increasing root $P$ uptake [97]. In addition, when attacked by pathogens, plants activate and assemble protective microbiomes, which help the plants resist and withstand diseases.

Previously, Rudrapa et al. [98] showed that malate efflux induces B. subtilis attraction to Arabidopsis roots during Pseudomonas syringae infection. The attracted B. subtilis triggered systemic resistance and protected plants against $P$. syringae. The "cry for help" concept was recently supported by a field experiment in which durum wheat naturally infected by Fusarium graminearum was enriched with Stenotrophomonas rhizophila in the rhizospheres and root endospheres to alleviate fungal disease [99]. This protection mechanism has not been described in banana plants. However, evidence shows that the microbial community shifts in banana plants infected by Fusarium, indicating a "cry for help" mechanism.

For example, Fusarium wilt disease has been reported to induce drastic alterations in the microbial endophyte diversity, especially $\gamma$-Proteobacteria and Bacteroidetes populations, in Cavendish bananas [91,100]. Lu et al. [101] observed attenuated Proteobacteria abundance in the roots, stems, and leaves from banana plants in a disease conducive orchard compared to the levels in a disease suppressive orchard. These authors also observed a $45 \%$ increase in Bacteroidetes abundance in the roots of plants in the disease suppressive orchard. Interestingly, Chryseobacterium, which belongs to the Bacteroidetes phylum, replaces these Proteobacteria strains. The increased abundance of Chryseobacterium as an endophyte or rhizosphere inhabitant has been related to its demonstrated antifungal protection and phosphate solubilization in various crops. In addition, plant protection against fungal pathogens is augmented when Chryseobacterium is placed in a network with Enterobacter, Pseudomonas, Bacillus, and Stenotrophomonas [102-105].

Lu et al. [101] also reported that the main change observed at the genus level in samples collected from the Fusarium wilt suppressive plantation was the abundance of Pseudomonas ( $\gamma$-Proteobacteria). Several Pseudomonas strains antagonistic to FocTR4 were collected from the disease suppressive orchards, with P. putida, P. aeruginosa, P. fluorescens, P. lutea, and P. monteilii being the most antagonistic. An increase in Sphingomonas $(\alpha-$ Proteobacteria), Agromyces (Actinobacteria), and Rhizobium ( $\alpha$-Proteobacteria) and a 7 -fold reduction in Bacillus were also observed in the suppressive orchards. This observation highlights the plant's urgency to acquire rapidly growing Proteobacteria that can transfer nutrients ( $\mathrm{N}$ and $\mathrm{P}$ ) to the plant and synthesize ACC deaminase and IAA auxin.

Liu et al. [91] detected a shift in the Enterobacteriaceae family during Fusarium wilt infection. The relative abundance of endospheric bacteria belonging to the Proteobacteria, Firmicutes and Actinobacteria phylum was positively associated with disease suppression, leading the authors to propose Klebsiella spp. as a keystone bacterium. Indeed, Pseudomonas, Enterobacter, and Klebsiella promote banana plant growth by modulating nitrogen fixation, phosphate solubilization, IAA production, and antifungal agents in plant tissues [106-108]. 
Additionally, Köberl et al. [100,109] showed that healthy banana plants collected in Fusarium wilt disease fields contained increased Pseudomonas and Stenotrophomonas abundance. It is plausible that these microorganisms could be health indicator markers. These $\gamma$-Proteobacteria were also found to increase in the microbiome of Gros Michel bananas grown under agroforestry conditions using Inga trees (green manure) for nitrogen fertilization [110].

Beyond the cultivar, geographic location, and fertilization management, it is consistent that a shift of banana endospheric microbial communities structure is consistently observed $[80,89]$. However, to understand the "cry for help" mechanism and keystone candidates relationship, we must combine biological and chemical approaches [111], especially when designing SynComs that promote resilience to all types of stresses. Despite the progress made, we still need to know if the observed changes of $\gamma$-Proteobacteria abundance in Fusarium-infected plants occur in other diseases such as black Sigatoka.

\subsection{Banana Endophyte Probiotics for Black Sigatoka}

In addition to Fusarium wilt or Panama disease, another fungus, Pseudocercospora fijiensis, threatens global banana production. This pathogen causes banana leaf necrosis, reducing their photosynthetic capacity, influencing the filling of the fruit, inducing premature ripening of fruit harvested, and consequently reducing the economic gain to zero [79].

In the 1960s, the appearance of the black Sigatoka disease completely modified the agricultural management of banana crops. An extensive application of chemical fungicides was used as a first option to combat this disease. However, this strategy quickly became ineffective due to the emergence of resistant and tolerant $P$. fijiensis populations to the chemical agents (e.g., carbendazim, azoxystrobin, propiconazole and mancozeb) $[5,112]$. Another strategy involved removing the leaves with lesions weekly (at the first streak stage) to reduce the amount of inoculum (ascospores). However, this practice reduced the number of functional leaves needed to maintain fruit quality once the banana bunch formed.

Once the $P$. fijiensis mycelium penetrates the stomata, after six days of epiphytic growth, it colonizes intercellular spaces and maintains a biotrophically relationship with the plant, behaving such as an endophyte. However, the plant's responses, including the production of hydrogen peroxide $\left(\mathrm{H}_{2} \mathrm{O}_{2}\right)$ and the fungal secretion of melanin pigment into the foliar tissue, modify the behavior of the fungus, transitioning from a biotrophic to a necrotrophic stage [113]. Therefore, the use of endophytic bacteria to reduce the impact of black Sigatoka appears to be a viable option.

Given the demand of the consumer market and the need for clean, sustainable agriculture, the world's banana production is shifting from conventional management practices towards certified organic practices. Biological products developed for managing black Sigatoka include plant extracts, Bacillus and Trichoderma spores, selected for their antifungal activity, and Saccharomyces cerevisiae (Agro-Mos) cell extracts [114]. However, the environmental conditions limit the biological control agent due to its low survival on the leaves or in the soil [78].

A few scientific works have reported the potential use of endophytes as biological control agents against black Sigatoka in both the laboratory and banana fields. In the Dominican Republic, Marcano et al. [115] showed the potential of endophytic Bacillus strains isolated from roots of Dwarf Cavendish against Sigatoka pathogen in vitro and in growth chamber assays. The best fungus controllers were B. licheniformis, B. siamensis, B. subtilis ssp. Inaquosorum, and Rhizobium massiliae. Notably, plants co-inoculated with bacteria and the pathogen displayed attenuated disease severity indices, an effect assigned to an induced systemic response (ISR) phenomenon.

In another study, previously mentioned in this review [87], a probiotic formulation of endophyte bacterial strains isolated from banana roots under organic management was developed. After a strict selection based on PGP-properties, two strains of Pseudomonas (P. plecoglossicida and P. taiwanensis) were found to retard foliar necrosis symptoms in field trials. The control plants presented necrosis symptoms from the first leaf (i.e., the youngest 
leaf). In contrast, plants treated with endophytic bacteria only showed necrosis symptoms at the fourth leaf (i.e., older). Furthermore, the fruit and the bunch's average weight was higher in banana plants treated with the endophyte probiotic bacteria.

Our research group has studied black Sigatoka from two scientific approaches to reduce the impact of black Sigatoka in bananas: a) the biochemistry and physiology of $P$. fijiensis and $b$ ) the endophytic bacteria populations and their usefulness as probiotics in commercial plantations of Colima and Jalisco, Mexico [5,18,116-118]. First, we proposed E. cloacae, which is widely distributed in banana plants and seeds $[18,30,119,120]$, as a keystone member of the microbial community of these plants. This endophyte serves as a plant-growth promoter, contributes to banana plant nutrition and imparts fungal disease tolerance $[33,80,100,110]$.

The E. cloacae (C2) strain studied in the laboratory (GenBank access KU93327) is a diazotrophic endophyte producer of siderophores and auxins with low ACC deaminase activity. This bacterium can inhibit different fungicide-resistant strains of $P$. fijiensis in vitro. Inoculation with the $\mathrm{C} 2$ strain has been shown to stimulate plant growth in the absence of nutrients, especially nitrogen. In this situation, plants 'consume' soil bacteria to obtain nutrients $[11,17,26,121]$. In this process, termed 'rhizophagy' or the 'rhizophagy cycle', soil bacteria are attracted to roots by root exudates, internalized into root cells at the root tips and subjected to superoxide secreted by root cells to extract nutrients from the internalized bacteria. Any surviving bacteria may be ejected back into soils from tips of root hairs thus that they can acquire additional nutrients $[11,18,26]$. Interestingly, an extended nutrient-transfer symbiosis is established in bananas, where E. cloacae appear to stably function in the rhizophagy cycle in banana roots [18]. The mechanism was verified by tracking ${ }^{15} \mathrm{~N}$ in pheophytin (a molecule derived from plant chlorophylls) after inoculation with ${ }^{15} \mathrm{~N}$-labeled E. cloacae. The relative abundances of pheophytin isotopomers indicate ${ }^{15} \mathrm{~N}$ label incorporation into three of the four nitrogen atoms of tetrapyrrole, confirming the N-transference from bacterium to plant tissues. Moreover, E. cloacae continued to be internalized into the banana roots after 60 days, a process that can be accelerated for up to 48 $\mathrm{h}$ in roots pretreated with silver nanoparticles (Macedo-Raygoza, personal communication).

A synthetic probiotic formula for the treatment of black Sigatoka has been developed. This microbial formula includes bacterial endophytic strains collected between 2009-2011 from functional leaves without apparent symptoms of black Sigatoka, including E. cloacae (C2), Bacillus velezensis (GenBank access. MT 919309), B. subtilis (Genbank access. MT919310) and Lysinibacillus sphaericus (Genbank access. MW486577) strains. This probiotic formula reduced the impact of fungal disease on naturally infected plantations in Colima, Mexico. After one year of applying this product, growers eliminated the requirement of administering chemical fungicides (e.g., mancozeb and propiconazole, typically applied every 5 and 15 days, respectively). Additionally, when the plantation transitioned to organic management, the applications of commercial plant extracts (e.g., Banacore ${ }^{\circledR}$, Biotika Gober $^{\circledR}$ and Timorex Gold ${ }^{\circledR}$ ) were reduced by $40-50 \%$. The probiotic inoculant is currently patent pending (PCT/Mx2021/000006 and MX/a/2021/002192) [119].

\section{Conclusions}

The use of plant probiotics can prevent plant disease, increase agriculture production, attenuate chemical inputs, and reduce greenhouse gas emissions, resulting in more sustainable agricultural practices. While the application of commercial bioinoculants is a good strategy for minimizing the use of agrochemicals, these products should only be employed after careful considerations. Indeed, the effects of applying large quantities of commercial Bacillus strains or other microbes on the native soil and endosphere microbial structures are still not fully understood.

However, microbial endophytes (bacteria and fungi) have been shown to benefit the host plants directly or indirectly by producing plant-promoting traits and helping to defend the plant against pathogens. Herein, we presented a substantial amount of information about the widely conserved endophytic bacterial communities and their potential roles 
as probiotics in Cavendish banana plants. However, there are challenges in applying the products to commercial plantations. Based on HTS and cultured-based methods, we also provided evidence that supports Chryseobacterium, Enterobacter, Klebsiella, Micrococcus, Paenibacillus, Pseudomonas Rhizobium, and Sphingophix as keystone taxa for banana plants.

Furthermore, under biotic stress conditions, especially Panama disease, shifts in banana endophyte communities have been reported. These observations provide valuable insights that can be used for developing bioinoculants composed of native endophytic bacteria that could be evaluated in field studies. SynComs are an attractive approach for alternative agricultural management strategies. Undoubtedly, endophytic probiotics represent a novel pathway for improving banana crop performance, especially in terms of enhancing banana resiliency to environmental stresses and fungal diseases such as Fusarium wilt and black Sigatoka disease

Author Contributions: Conceptualization, M.J.B.-G., J.F.W., P.D.M., B.V.-S.; investigation M.J.B.-G. and B.V.-S.; data curation A.M.-R., I.O.-A., Y.Y.C.-C.; writing-original draft preparation, M.J.B.-G., A.M.-R., I.O.-A., J.F.W.; writing-review and editing, M.J.B.-G., J.F.W., P.D.M., B.V.-S.; visualization, M.J.B.-G., A.M.-R., Y.Y.C.-C.; project administration M.J.B.-G. and A.M.-R.; funding acquisition, M.J.B.-G., J.F.W., P.D.M. All authors have read and agreed to the published version of the manuscript.

Funding: This research was funded by FODECIJAL, the Council of Science and Technology of Jalisco, project number 8022-2019; funding support was also provided to JFW from the USDANIFA Multistate Project W4147 and the New Jersey Agricultural Experiment Station. The APC was funded by project number 8022-2019, the USDA-NIFA Multistate Project W4147, and the New Jersey Agricultural Experiment Station.

Acknowledgments: We are grateful to the Coliman group for giving us access to their banana fields in Tecoman, Colima, Mexico. MJB-G thanks the National Council of Science and Technology of Mexico and the Sistema Nacional de Investigadores for fellowship CVU-32163 and Universidad Autónoma de Guadalajara for the fellowship "Plan de Carrera-UAG". AM-R thanks the National Council of Science and Technology of Mexico and the MYDCI-UABC program support for Ph.D. studies (Fellowship number CVU-720754). IO-R thanks the National Council of Science and Technology of Mexico and the MYDCI-UABC program support for MSc studies (Fellowship number CVU1061597). PDM thanks FAPESP (Fundação de Amparo à Pesquisa do Estado de São Paulo)—Paolo Di Mascio No. 2012/12663-1, CEPID Redoxoma-No. 2013/07937-8, CNPq (Conselho Nacional para o Desenvolvimento Científico e Tecnológico-No. 302120/2018-1 and PRPUSP (Pró-Reitoria de Pesquisa da Universidade de São Paulo, NAP Redoxoma no. 2011.1.9352.1.8) for financial support. Funding support was also provided to JFW from the USDA-NIFA Multistate Project W4147 and the New Jersey Agricultural Experiment Station.

Conflicts of Interest: The authors declare no conflict of interest.

\section{References}

1. Food and Agriculture Organization of the United Nations, Teams on International Investment and Tropical fruits Trade and Market Division. Banana Market Review: Preliminary Results. 2019. Available online: http://www.fao.org/faostat/en/?\#data/QC (accessed on 28 June 2021).

2. Scott, G.J. A review of root, tuber and banana crops in developing countries: Past, present and future. Int. J. Food Sci. Technol. 2021, 56, 1093-1114. [CrossRef]

3. Panigrahi, N.; Thompson, A.; Zubelzu, S.; Knox, J. Identifying opportunities to improve management of water stress in banana production. Sci. Hortic. 2020, 276, 109735. [CrossRef]

4. Meya, A.; Ndakidemi, P.; Mtei, K.; Swennen, R.; Merckx, R. Optimizing soil fertility management strategies to enhance banana production in volcanic soils of the Northern Highlands, Tanzania. Agronomy 2020, 10, 289. [CrossRef]

5. Aguilar-Barragan, A.; García-Torres, A.; Odriozola-Casas, O.; Macedo-Raygoza, G.; Ogura, T.; Manzo-Sánchez, G.; James, A.; Islas-Flores, I.; Beltran-García, M. Chemical management in fungicide sensivity of Mycosphaerella fijiensis collected from banana fields in México. Braz. J. Microbiol. 2014, 45, 359-364. [CrossRef] [PubMed]

6. Dita, M.; Barquero, M.; Heck, D.; Mizubuti, E.S.G.; Staver, C.P. Fusarium wilt of banana: Current knowledge on epidemiology and research needs toward sustainable disease management. Front. Plant Sci. 2018, 9, 1468. [CrossRef] [PubMed]

7. Thangavelu, R.; Saraswathi, M.S.; Uma, S.; Loganathan, M.; Backiyarani, S.; Durai, P.; Raj, E.E.; Marimuthu, N.; Kannan, G.; Swennen, R. Identification of sources resistant to a virulent Fusarium wilt strain (VCG 0124) infecting Cavendish bananas. Sci. Rep. 2021, 11, 3183. [CrossRef] 
8. Raphael, L.; Recous, S.; Ozier-Lafontaine, H.; Sierra, J. Fate of a 15N-labeled urea pulse in heavily fertilized banana crops. Agronomy 2020, 10, 666. [CrossRef]

9. Aryal, D.R.; Geissen, V.; Ponce-Mendoza, A.; Ramos-Reyes, R.; Becker, M. Water quality under intensive banana production and extensive pastureland in tropical Mexico. J. Soil. Sci. Plant Nutr. 2012, 175, 553-559. [CrossRef]

10. White, J.F.; Chang, X.; Kingsley, K.L.; Zhang, Q.; Chiaranunt, P.; Micci, A.; Velazquez, F.; Elmore, M.; Crane, S.; Li, S.; et al. Endophytic bacteria in grass crop growth promotion and biostimulation. Grass Res. 2021, 1, 1-9. [CrossRef]

11. Souza, R.; Ambrosini, A.; Passaglia, L.M. Plant growth-promoting bacteria as inoculants in agricultural soils. Genet. Mol. Biol. 2015, 38, 401-419. [CrossRef]

12. Ambrosini, A.; de Souza, R.; Passaglia, L.M.P. Ecological role of bacterial inoculants and their potential impact on soil microbial diversity. Plant Soil. 2016, 400, 193-207. [CrossRef]

13. White, J.F.; Kingsley, K.L.; Zhang, Q.; Verma, R.; Obi, N.; Dvinskikh, S.; Elmore, M.T.; Verma, S.K.; Gond, S.K.; Kowalski, K.P. Endophytic microbes and their potential applications in crop management. Pest. Manag. Sci. 2019, 10, 2558-2565. [CrossRef] [PubMed]

14. Vandana, U.K.; Rajkumari, J.; Singha, L.P.; Satish, L.; Alavilli, H.; Sudheer, P.D.V.N.; Chauhan, S.; Ratnala, R.; Satturu, V.; Mazumder, P.B.; et al. The endophytic microbiome as a hotspot of synergistic interactions, with prospects of plant growth promotion. Biology 2021, 10, 101. [CrossRef] [PubMed]

15. Thomas, P.; Sekhar, A.C. Live cell imaging reveals extensive intracellular cytoplasmic colonization of banana by normally non-cultivable endophytic bacteria. AoB Plants 2014, 6, plu002. [CrossRef] [PubMed]

16. Thomas, P.; Franco, C.M.M. Intracellular bacteria in Plants: Elucidation of abundant and diverse cytoplasmic bacteria in healthy plant cells using in vitro cell and callus cultures. Microorganisms 2021, 28, 269. [CrossRef] [PubMed]

17. Beltran-Garcia, M.J.; White, J.F., Jr.; Prado, F.M.; Prieto, K.R.; Yamaguchi, L.F.; Torres, M.S.; Kato, M.J.; Medeiros, M.H.G.; Di Mascio, P. Nitrogen acquisition in Agave tequilana from degradation of endophytic bacteria. Sci. Rep. 2014, 4, 1-7. [CrossRef]

18. Macedo-Raygoza, G.M.; Valdez, B.S.; Prado, F.M.; Prieto, K.R.; Yamaguchi, L.F.; Kato, M.J.; Canto-Canche, B.B.; Carrillo-Beltran, M.; Di Mascio, P.; White, J.F.; et al. Enterobacter cloacae, an endophyte that establishes a nutrient-transfer symbiosis with banana plants and protects against the black Sigatoka pathogen. Front. Microbiol. 2019, 10, 804. [CrossRef]

19. Dini-Andreote, F. Endophytes: The second layer of plant defense. Trends Plant Sci. 2020, 25, 319-322. [CrossRef]

20. Bradshaw, M.J.; Pane, A.M. Field inoculations of nitrogen fixing endophytes on turfgrass. Physiol. Mol. Plant Pathol. 2020, 112, 101557. [CrossRef]

21. Gupta, S.; White, J.; Kulkarni, M. An outlook on current and future directions in Endophyte research. Editorial Note-Endophyte Special Issue (South African Journal of Botany). S Afr. J. Bot. 2020, 134, 1-2. [CrossRef]

22. Babalola, O.O.; Fadiji, A.E.; Enagbonma, B.J.; Alori, E.T.; Ayilara, M.S.; Ayangbenro, A.S. The nexus between plant and plant microbiome: Tevelation of the networking strategies. Front. Microbiol. 2020, 11, 548037. [CrossRef]

23. Ray, P.; Lakshmanan, V.; Labbé, J.L.; Craven, K.D. Microbe to Microbiome: A paradigm shift in the application of microorganisms for sustainable agriculture. Front. Microbiol. 2020, 11, 622926. [CrossRef] [PubMed]

24. Xiong, W.; Guo, S.; Jousset, A.; Zhao, Q.; Wu, H.; Rong, L.; Kowalchuk, G.; Shen, Q. Bio-fertilizer application induces soil suppressiveness against Fusarium wilt disease by reshaping the soil microbiome. Soil. Biol. Biochem. 2017, 114, 238-247. [CrossRef]

25. Liu, H.; Carvalhais, L.C.; Crawford, M.; Singh, E.; Dennis, P.G.; Pieterse, C.M.J.; Schenk, P.M. Inner plant values: Diversity, colonization and benefits from endophytic bacteria. Front. Microbiol. 2017, 8, 2552. [CrossRef]

26. White, J.F.; Kingsley, K.L.; Verma, S.K.; Kowalski, K.P. Rhizophagy cycle: An oxidative process in plants for nutrient extraction from symbiotic microbes. Microorganisms 2018, 6, 95. [CrossRef] [PubMed]

27. Hardoim, P.R.; van Overbeek, L.S.; Berg, G.; Pirttilä, A.M.; Compant, S.; Campisano, A.; Döring, M.; Sessitsch, A. The hidden world within plants: Ecological and evolutionary considerations for defining functioning of microbial endophytes. Microbiol. Mol. Biol. Rev. 2015, 79, 293-320. [CrossRef]

28. Santoyo, G.; Moreno-Hagelsiebb, G.; Orozco-Mosqueda, M.C.; Glick, B.R. Plant growth-promoting bacterial endophytes. Microbiol. Res. 2016, 183, 92-99. [CrossRef] [PubMed]

29. Vorholt, J.A. Microbial life in the phyllosphere. Nat. Rev. Microbiol. 2012, 10, 828-840. [CrossRef]

30. Thomas, P.; Swarna, G.K.; Patil, P.; Rawal, R. Ubiquitous presence of normally non-culturable endophytic bacteria in field shoot-tips of banana and their gradual activation to quiescent cultivable form in tissue cultures. Plant Cell Tiss. Organ Cult. 2008, 93, 39-54. [CrossRef]

31. Thomas, P.; Swarna, G.K.; Roy, P.K.; Patil, P. Identification of culturable and originally non-culturable endophytic bacteria isolated from shoot tip cultures of banana cv. Grand Naine. Plant Cell Tiss. Organ Cult. 2008, 93, 55-63. [CrossRef]

32. Kaushal, M.; Mahuku, G.; Swennen, R. Metagenomic insights of the root colonizing microbiome associated with symptomatic and non-symptomatic bananas in Fusarium wilt infected fields. Plants 2020, 9, 63. [CrossRef] [PubMed]

33. Cabanás, G.-L.C.; Fernández-González, A.J.; Cardoni, M.; Valverde-Corredor, A.; López-Cepero, J.; Fernández-López, M.; Mercado-Blanco, J. The Banana root endophytome: Differences between mother plants and suckers and evaluation of selected bacteria to control Fusarium oxysporum f.sp. cubense. J. Fungi 2021, 7, 194. [CrossRef]

34. Anguita-Maeso, M.; Olivares-García, C.; Haro, C.; Imperial, J.; Navas-Cortés, J.A.; Landa, B.B. Culture-dependent and cultureindependent characterization of the olive xylem microbiota: Effect of sap extraction methods. Front. Plant Sci. 2020, 10, 700-711. [CrossRef] 
35. Aghdam, S.A.; Brown, A.M.V. Deep learning approaches for natural product discovery from plant endophytic microbiomes. Environ. Microbiome 2021, 16, 1-20. [CrossRef] [PubMed]

36. Du, X.; Zhai, Y.; Deng, Q.; Tan, H.; Cao, L. Illumina-Based sequencing analysis directed selection for actinobacterial probiotic candidates for banana plants. Probiotics Antimicrob. Proteins 2018, 10, 284-292. [CrossRef] [PubMed]

37. Ma, Q.; Bücking, H.; Gonzalez Hernandez, J.L.; Subramanian, S. Single-Cell RNA sequencing of plant-associated bacterial communities. Front. Microbiol. 2019, 10, 2452. [CrossRef]

38. Liu, C.; Dong, Y.; Hou, L.; Deng, N.; Jiao, R. Acidobacteria community responses to nitrogen dose and form in chinese fir plantations in southern China. Curr. Microbiol. 2017, 74, 396-403. [CrossRef]

39. Fadiji, A.E.; Ayangbenro, A.S.; Babalola, O.O. Metagenomic profiling of the community structure, diversity, and nutrient pathways of bacterial endophytes in maize plant. Antonie Van Leeuwenhoek 2020, 113, 1559-1571. [CrossRef] [PubMed]

40. Reva, O.N.; Swanevelder, D.Z.H.; Mwita, L.A.; Mwakilili, A.D.; Muzondiwa, D.; Joubert, M.; Chan, W.Y.; Lutz, S.; Ahrens, C.H.; Avdeeva, L.V.; et al. Genetic, epigenetic and phenotypic diversity of four Bacillus velezensis strains used for plant protection or as probiotics. Front. Microbiol. 2019, 10, 2610. [CrossRef]

41. Mastan, A.; Rane, D.; Dastager, S.G.; Vivek-Babu, C.S. Plant probiotic bacterial endophyte, Alcaligenes faecalis, modulates plant growth and forskolin biosynthesis in Coleus forskohlii. Probiotics Antimicrob. Proteins 2020, 12, 481-493. [CrossRef]

42. Jayakumar, A.; Padmakumar, P.; Nair, I.; Krishnankutty, R. Drought tolerant bacterial endophytes with potential plant probiotic effects from Ananas comosus. Biologia 2020, 75, 1769-1778. [CrossRef]

43. Cueva-Yesquén, L.G.; Goulart, M.C.; Attili de Angelis, D.; Nopper Alves, M.; Fantinatti-Garboggini, F. Multiple plant growthpromotion traits in Endophytic Bacteria retrieved in the vegetative stage from passion flower. Front. Plant Sci. 2021, 11, 2282. [CrossRef]

44. Saha, C.; Mukherjee, G.; Agarwal-Banka, P.; Seal, A. A consortium of non-rhizobial endophytic microbes from Typha angustifolia functions as probiotic in rice and improves nitrogen metabolism. Plant Biol. 2016, 18, 938-946. [CrossRef] [PubMed]

45. Martínez-Rodríguez, J.; De la Mora-Amutio, M.; Plascencia-Correa, L.A.; Audelo-Regalado, E.; Guardado, F.R.; HernándezSánchez, E.; Peña-Ramírez, Y.J.; Escalante, A.; Beltrán-García, M.J.; Ogura, T. Cultivable endophytic bacteria from leaf bases of Agave tequilana and their role as plant growth promoters. Braz. J. Microbiol. 2015, 45, 1333-1339. [CrossRef] [PubMed]

46. Martinez-Rodriguez, A.; Macedo-Raygoza, G.; Huerta, A.; Reyes-Sepulveda, I.; Lozano-Lopez, J.; García-Ochoa, E.; Fierro-Kong, L.; Medeiros, M.; Di Mascio, P.; White, J.; et al. Agave seed endophytes: Ecology and impacts on root architecture, nutrient acquisition, and cold stress tolerance. Seed Endophytes. Springer 2019, 5, 139-170.

47. Kazerooni, E.A.; Maharachchikumbura, S.S.N.; Adhikari, A.; Al-Sadi, A.M.; Kang, S.M.; Kim, L.R.; Lee, I.J. Rhizospheric Bacillus amyloliquefaciens protects Capsicum annuum cv. Geumsugangsan from multiple abiotic stresses via multifarious plant growth-promoting attributes. Front. Plant Sci. 2021, 12, 12. [CrossRef]

48. Orozco-Mosqueda, M.D.C.; Glick, B.R.; Santoyo, G. ACC deaminase in plant growth-promoting bacteria (PGPB): An efficient mechanism to counter salt stress in crops. Microbiol. Res. 2020, 235, 126439. [CrossRef]

49. Orozco-Mosqueda, M.C.; Flores, A.; Rojas-Sánchez, B.; Urtis-Flores, C.A.; Morales-Cedeño, L.R.; Valencia-Marin, M.F.; ChávezAvila, S.; Rojas-Solis, D.; Santoyo, G. Plant growth-promoting bacteria as bioinoculants: Attributes and challenges for sustainable crop improvement. Agronomy 2021, 11, 50. [CrossRef]

50. Adhikari, P.; Pandey, A. Bioprospecting plant growth promoting endophytic bacteria isolated from Himalayan yew (Taxus wallichiana Zucc.). Microbiol. Res. 2020, 239, 126536. [CrossRef]

51. Chen, L.; Wu, Y.D.; Chong, X.Y.; Xin, Q.H.; Wang, D.X.; Bian, K. Seed-borne endophytic Bacillus velezensis LHSB1 mediate the biocontrol of peanut stem rot caused by Sclerotium rolfsii. J. Appl. Microbiol. 2020, 128, 803-813. [CrossRef]

52. Zheng, T.; Liu, L.; Nie, Q.; Hsiang, T.; Sun, Z.; Zhou, Y. Isolation, identification and biocontrol mechanisms of endophytic bacterium D61-A from Fraxinus hupehensis against Rhizoctonia solani. Biological. Control. 2021, 158, 104621. [CrossRef]

53. López, S.M.Y.; Pastorino, G.N.; Balatti, P.A. Volatile organic compounds profile synthesized and released by endophytes of tomato (Solanum lycopersici L.) and their antagonistic role. Arch. Microbiol. 2021, 203, 1383-1397. [CrossRef]

54. Merino-Martin, L.; Stokes, A.; Gweon, H.; Moragues, L.; Staunton, S.; Plassard, C.; Oliver, A.; Le Bissonnais, Y.; Griffiths, R. Interacting effects of land use type, microbes and plant traits on soil aggregate stability. Soil Biol. Biochem. 2021, 154, 108072. [CrossRef]

55. Du, J.; Li, Y.; Yin, Z.; Wang, H.; Zhang, X.; Ding, X. High-throughput customization of plant microbiomes for sustainable agriculture. Front. Plant Sci. 2020, 11, 11. [CrossRef] [PubMed]

56. Rodriguez, P.; Rothballer, M.; Paul Chowdhury, S.; Nussbaumer, T.; Gutjahr, C.; Falter-Braun, P. Systems biology of plantmicrobiome interactions. Mol. Plant 2019, 12, 804-821. [CrossRef]

57. De Souza, R.S.C.; Armanhi, J.S.L.; Arruda, P. From microbiome to traits: Designing synthetic microbial communities for improved crop resiliency. Front. Plant Sci. 2020, 11, 11. [CrossRef] [PubMed]

58. Saad, M.; Eida, A.A.; Hirt, H. Tailoring plant-associated microbial inoculants in agricultura-A roadmap for successful application. J. Exp. Bot. 2020, 71, 3878-3901. [CrossRef]

59. Ke, J.; Wang, B.; Yoshikuni, Y. Microbiome engineering: Synthetic biology of plant-associated microbiomes in sustainable agriculture. Trends Biotechnol. 2021, 39, 244-261. [CrossRef]

60. Marín, O.; González, B.; Poupin, M.J. From microbial dynamics to functionality in the rhizosphere: A systematic review of the opportunities with synthetic microbial communities. Front. Plant Sci. 2021, 12, 12. [CrossRef] 
61. Ma, K.W.; Niu, Y.; Jia, Y.; Ordon, J.; Copeland, C.; Emonet, A.; Geldner, N.; Guan, R.; Stolze, S.C.; Nakagami, H.; et al. Coordination of microbe-host homeostasis by crosstalk with plant innate immunity. Nat. Plants 2021, 7, 814-825. [CrossRef]

62. Yin, J.; Yu, Y.; Zhang, Z.; Chen, L.; Ruan, L. Enrichment of potentially beneficial bacteria from the consistent microbial community confers canker resistance on tomato. Microbiol. Res. 2020, 234, 126446. [CrossRef] [PubMed]

63. Carrión, V.J.; Perez-Jaramillo, J.; Cordovez, V.; Tracanna, V.; de Hollander, M.; Ruiz-Buck, D.; Mendes, L.W.; van Ijcken, W.F.J.; Gomez-Exposito, R.; Elsayed, S.S.; et al. Pathogen-induced activation of disease-suppressive functions in the endophytic root microbiome. Science 2019, 366, 606-612. [CrossRef]

64. Niu, B.; Paulson, J.; Zheng, X.; Kolter, R. Simplified and representative bacterial community of maize roots. Proc. Natl. Acad. Sci. USA 2017, 114, E2450-E2459. [CrossRef] [PubMed]

65. Finkel, O.M.; Salas-González, I.; Castrillo, G.; Conway, J.M.; Law, T.F.; Teixeira, P.J.P.L.; Wilson, E.D.; Fitzpatrick, C.R.; Jones, C.D.; Dangl, J.L. A single bacterial genus maintains root growth in a complex microbiome. Nature 2020, 587, 103-108. [CrossRef]

66. Wu, L.; Yang, B.; Li, M.; Chen, J.; Xiao, Z.; Wu, H.; Tong, Q.; Luo, X.; Lin, W. Modification of rhizosphere bacterial community structure and functional potentials to control Pseudostellaria heterophylla replant disease. Plant Dis. 2020, 104, 25-34. [CrossRef]

67. Durán, P.; Thiergart, T.; Garrido-Oter, R.; Agler, M.; Kemenm, E.; Schulze-Lefert, P.; Hacquard, S. Microbial interkingdom interactions in roots promote Arabidopsis survival. Cell 2018, 175, 973-983. [CrossRef]

68. Knoth, J.; Kim, S.H.; Ettl, G.; Doty, S. Biological nitrogen fixation and biomass accumulation within poplar clones as a result of inoculations with diazotrophic endophyte consortia. New Phytol. 2014, 201, 599-609. [CrossRef]

69. Finkel, O.M.; Salas-González, I.; Castrillo, G.; Spaepen, S.; Law, T.F.; Teixeira, P.J.P.L.; Jones, C.D.; Dangl, J.L. The effects of soil phosphorus content on plant microbiota are driven by the plant phosphate starvation response. PLoS Biol. 2019, 17, e3000534. [CrossRef]

70. Zhang, J.; Liu, Y.X.; Zhang, N.; Hu, B.; Jin, T.; Xu, H.; Qin, Y.; Yan, P.; Zhang, X.; Guo, X.; et al. NRT1.1B is associated with root microbiota composition and nitrogen use in field-grown rice. Nat. Biotechnol. 2019, 37, 676-684. [CrossRef]

71. Brown, K.B.; Hyde, K.; Guest, D. Preliminary studies on endophytic fungal communities of Musa acuminata species complex in Hong Kong and Australia. Fungal Divers. 1998, 1, 27-51.

72. Pereira, J.; Vieira, M.C.; Azevedo, J. Endophytic fungi from Musa acuminata and their reintroduction into axenic plants. World J. Microbiol. Biotechnol. 1999, 15, 37-40. [CrossRef]

73. Sikora, R.A.; Schuster, R.F.; Griesbach, M. Improved plant health through biological enhancement of banana planting material with mutualistic endophytes. Acta Hortic. 2000, 540, 409-413. [CrossRef]

74. Martinez, L.; Caballero-Mellado, J.; Orozco, J.; Martínez-Romero, E. Diazotrophic bacteria associated with banana (Musa spp.). Plant Soil. 2003, 257, 35-47. [CrossRef]

75. Cao, L.; Qiu, Z.; You, J.; Tan, H.; Zhou, S. Isolation and characterization of endophytic Streptomycete antagonists of Fusarium wilt pathogen from surface-sterilized banana roots. FEMS Microbiol. Lett. 2006, 247, 147-152. [CrossRef] [PubMed]

76. Thomas, P.; Soly, T.A. Endophytic bacteria associated with growing shoot tips of banana (Musa sp.) cv. Grand Naine and the affinity of endophytes to the host. Microb. Ecol. 2009, 58, 952-964. [CrossRef] [PubMed]

77. Thomas, P.; Reddy, K. Microscopic elucidation of abundant endophytic bacteria colonizing the cell wall-plasma membrane peri-space in the shoot-tip tissue of banana. AoB Plants 2013, 5, 5. [CrossRef]

78. Thomas, P.; Sekhar, A.C. Effects due to rhizospheric soil application of an antagonistic bacterial endophyte on native bacterial community and its survival in soil: A case study with Pseudomonas aeruginosa from banana. Front. Microbiol. 2016, 7, 7. [CrossRef]

79. Arango-Isaza, R.E.; Diaz-Trujillo, C.; Dhillon, B.; Aerts, A.; Carlier, J.; Crane, C.F.; de Jong, T.; de Vries, I.; Dietrich, R.; Farmer, A.D.; et al. Combating a global threat to a clonal crop: Banana Black Sigatoka pathogen Pseudocercospora fijiensis (Synonym Mycosphaerella fijiensis) genomes reveal clues for disease control. PLoS Genet. 2016, 12, 12. [CrossRef]

80. Nakkeeran, S.; Rajamanickam, S.; Saravanan, R.; Vanthana, M.; Soorianathasundaram, K. Bacterial endophytome-mediated resistance in banana for the management of Fusarium wilt. Biotech 2021, 11, 11.

81. Thomas, P.; Sekhar, A.C. Cultivation Versus Molecular Analysis of Banana (Musa sp.) Shoot-Tip tissue reveals enormous diversity of normally uncultivable endophytic bacteria. Microb. Ecol. 2017, 73, 885-899. [CrossRef]

82. Rossmann, B.; Müller, H.; Smalla, K.; Mpiira, S.; Tumuhairwe, J.B.; Staver, C.; Berg, G. Banana-associated microbial communities in Uganda are highly diverse but dominated by Enterobacteriaceae. Appl. Environ. Microbiol. 2012, 78, 4933-4941. [CrossRef]

83. Ngamau, C.N.; Matiru, V.N.; Tani, A.; Murthuri, C.W. Isolation and identification of endophytic bacteria of bananas (Musa spp.) in Kenya and their potential as biofertilizers for sustainable banana production. Afr. J. Microbiol. Res. 2012, 6, 6414-6422.

84. Souza, S.; Xavier, A.; Costa, M.; Cardoso, A.; Pereira, M.; Nietsche, S. Endophytic bacterial diversity in banana 'Prata Anã' (Musa spp.) roots. Genet. Mol. Biol. 2013, 36, 252-264. [CrossRef] [PubMed]

85. Andrade, L.F.; de Souza, G.L.; Nietsche, S.; Xavier, A.A.; Costa, M.R.; Cardoso, A.M.; Pereira, M.C.; Pereira, D.F. Analysis of the abilities of endophytic bacteria associated with banana tree roots to promote plant growth. J. Microbiol. 2014, 52, 27-34. [CrossRef] [PubMed]

86. Pereira, D.; Nietsche, S.; Xavier, A.; Souza, S.; Costa, M.; Duarte, A. Characterization and activity of endophytic bacteria from 'Prata Anã' banana crop (Musa sp., AAB). Rev. Ceres 2018, 65, 381-387. [CrossRef]

87. Marcano, I.E.; Díaz-Alcántara, C.A.; Urbano, B.; González-Andrés, F. Assessment of bacterial populations associated with banana tree roots and development of successful plant probiotics for banana crop. Soil Biol. Biochem. 2016, 99, 1-20. [CrossRef] 
88. Karthik, M.; Periyasamy, P.; Ramasamy, K.; Murugaiyan, S. Endophytic bacteria associated with banana cultivars and their inoculation effect on plant growth. J. Hortic. Sci. Biotechnol. 2017, 92, 1-9. [CrossRef]

89. Beltran-Garcia, M.J.; Martínez-Rodríguez, A.; Olmos-Arriaga, I.; Valdes-Salas, B.; Di Mascio, P.; White, J. Nitrogen fertilization and stress factors drive shifts in microbial diversity in soils and plants. Symbiosis 2021, 1, 1-12.

90. Fan, K.; Delgado-Baquerizo, M.; Guo, X.; Wang, D.; Wu, Y.; Zhu, M.; Yu, W.; Yao, H.; Zhu, Y.; Chu, H. Suppressed N fixation and diazotrophs after four decades of fertilization. Microbiome 2019, 7, 7. [CrossRef]

91. Liu, Y.; Zhu, A.; Tan, H.; Cao, L.; Zhang, R. Engineering banana endosphere microbiome to improve Fusarium wilt resistance in banana. Microbiome 2019, 7, 7. [CrossRef]

92. Wagg, C.; Schlaeppi, K.; Banerjee, S.; Kuramae, E.; Van der Heijden, M. Fungal-bacterial diversity and microbiome complexity predict ecosystem functioning. Nat. Commun. 2019, 10, 1-10. [CrossRef]

93. Banerjee, S.; Schlaeppi, K.; van der Heijden, M.G.A. Keystone taxa as drivers of microbiome structure and functioning. Nat. Rev. Microbiol. 2018, 16, 567-576. [CrossRef] [PubMed]

94. Banerjee, S.; Walder, F.; Büchi, L.; Meyer, M.; Held, A.Y.; Gattinger, A.; Keller, T.; Charles, R.; van der Heijden, M.G.A. Agricultural intensification reduces microbial network complexity and the abundance of keystone taxa in roots. ISME J. 2019, 13, 1722-1736. [CrossRef]

95. Yin, C.; Casa Vargas, J.M.; Schlatter, D.C.; Hagerty, C.H.; Hulbert, S.H.; Paulitz, T.C. Rhizosphere community selection reveals bacteria associated with reduced root disease. Microbiome 2021, 9, 86. [CrossRef]

96. Rolfe, S.A.; Griffiths, J.; Ton, J. Crying out for help with root exudates: Adaptive mechanisms by which stressed plants assemble health-promoting soil microbiomes. Curr. Opin. Microbiol. 2019, 49, 73-82. [CrossRef] [PubMed]

97. Wang, Y.; Lambers, H. Root-released organic anions in response to low phosphorus availability: Recent progress, challenges and future perspectives. Plant Soil. 2020, 447, 135-156. [CrossRef]

98. Rudrappa, T.; Czymmek, K.J.; Paré, P.W.; Bais, H.P. Root-secreted malic acid recruits beneficial soil bacteria. Plant Physiol. 2008, 148, 1547-1556. [CrossRef]

99. Liu, H.; Li, J.; Carvalhais, L.C.; Percy, C.D.; Prakash Verma, J.; Schenk, P.M.; Singh, B.K. Evidence for the plant recruitment of beneficial microbes to suppress soil-borne pathogens. New Phytol. 2021, 229, 2873-2885. [CrossRef] [PubMed]

100. Köberl, M.; Dita, M.; Martinuz, A.; Staver, C.; Berg, G. Members of Gammaproteobacteria as indicator species of healthy banana plants on Fusarium wilt-infested fields in Central America. Sci. Rep. 2017, 7, 1-9. [CrossRef]

101. Lu, N.; Zongzhuan, S.; Chengyuan, T.; Yannan, O.; Beibei, W.; Yunze, R.; Rong, L.; Qirong, S. The characteristics of culturable bacterial community in soils and tissue parts of banana. Nanjing Nong Ye Da Xue Xue Bao 2019, 42, 1088-1097.

102. Sang, M.K.; Jeong, J.J.; Kim, J.; Kim, K.D. Growth promotion and root colonisation in pepper plants by phosphate-solubilising Chryseobacterium sp. strain ISE14 that suppresses Phytophthora blight. Ann. Appl. Biol. 2018, 172, 208-223. [CrossRef]

103. Alsultan, W.; Vadamalai, G.; Ahmad, K.; Halimi, M.; Al-Sadi, A.; Rashed, O.; Mohd Jaaffar, A.K.; Nasehi, A. Isolation, identification and characterization of endophytic bacteria antagonistic to Phytophthora palmivora causing black pod of cocoa in Malaysia. Eur. J. Plant Pathol. 2019, 155, 1077-1091. [CrossRef]

104. Jasrotia, S.; Salgotra, R.K.; Sharma, M. Efficacy of bioinoculants to control of bacterial and fungal diseases of rice (Oryza sativa L.) in northwestern Himalaya. Braz. J. Microbiol. 2021, 52, 687-704. [CrossRef] [PubMed]

105. Shi, W.; Su, G.; Li, M.; Wang, B.; Lin, R.; Yang, Y.; Wei, T.; Zhou, B.; Gao, Z. Distribution of bacterial endophytes in the non-lesion tissues of potato and their response to potato common scab. Front. Microbiol. 2021, 12, 12. [CrossRef] [PubMed]

106. De Lima, D.R.M.; Dos Santos, I.B.; Oliveira, J.T.C.; da Costa, D.P.; de Queiroz, J.V.J.; Romagnoli, E.M.; Andreote, F.D.; Freire, F.J.; Kuklinsky-Sobral, J. Genetic diversity of N-fixing and plant growth-promoting bacterial community in different sugarcane genotypes, association habitat and phenological phase of the crop. Arch. Microbiol. 2021, 203, 1089-1105. [CrossRef]

107. Korshunova, T.Y.; Bakaeva, M.D.; Kuzina, E.V.; Rafikova, G.F.; Chetverikov, S.P.; Chetverikova, D.V.; Loginov, O.N. Role of bacteria of the genus Pseudomonas in the sustainable development of agricultural systems and environmental protection (Review). J. Appl. Microbiol. Biochem. 2021, 57, 281-296. [CrossRef]

108. Gang, S.; Sharma, S.; Saraf, M.; Buck, M.; Schumacher, J. Bacterial indole-3-acetic acid influences soil nitrogen acquisition in barley and chickpea. Plants 2021, 10, 780. [CrossRef]

109. Köberl, M.; Dita, M.; Nimusiima, J.; Tumuhairwe, J.; Kubiriba, J.; Staver, C.; Berg, G. The banana microbiome: Stability and potential health indicators. Acta Hortic. 2018, 1196, 1-8. [CrossRef]

110. Oljira, A.M.; Hussain, T.; Waghmode, T.R.; Zhao, H.; Sun, H.; Liu, X.; Wang, X.; Liu, B. Trichoderma enhances net photosynthesis, water use efficiency, and growth of wheat (Triticum aestivum L.) under salt stress. Microorganisms 2020, 8, 1565. [CrossRef]

111. Rizaludin, M.S.; Stopnisek, N.; Raaijmakers, J.; Garbeva, P. The chemistry of stress: Understanding the 'Cry for Help' of plant roots. Metabolites 2021, 11, 357. [CrossRef]

112. Chong, P.; Essoh, J.N.; Arango-Isaza, R.E.; Keizer, P.; Stergiopoulos, I.; Seidl, M.F.; Guzman, M.; Sandoval, J.; Verweij, P.E.; Scalliet, G.; et al. A world-wide analysis of reduced sensitivity to DMI fungicides in the banana pathogen Pseudocercospora fijiensis. Pest. Manag. Sci. 2021, 77, 3273-3288. [CrossRef]

113. Beltrán-García, M.J.; Prado, F.M.; Oliveira, M.S.; Ortiz-Mendoza, D.; Scalfo, A.C.; Pessoa, A., Jr.; Medeiros, M.H.; White, J.F.; Di Mascio, P. Singlet molecular oxygen generation by light-activated DHN-melanin of the fungal pathogen Mycosphaerella fijiensis in black Sigatoka disease of bananas. PLoS ONE 2014, 9, e091616. [CrossRef] [PubMed] 
114. Becker, P.; Eskerc, P.; Umaña, G. Incorporation of microorganisms to reduce chemical fungicide usage in black Sigatoka control programs in Costa Rica by use of biological fungicides. Crop Prod. 2021, 146, 105657. [CrossRef]

115. Marcano, I.E.; Díaz-Alcántara, C.A.; Seco, V.; Urbano, B.; González-Andrés, F. Induced Systemic Resistance Could Explain the Reduction in the Incidence of Black Sigatoka (Mycosphaerella fijiensis) in Banana Plants Inoculated with Bacteria Isolated from Banana Tree Roots in the Dominican Republic. In Bacteria Isolated from Banana Tree Roots in the Dominican Republic; GonzálezAndrés, F., James, E., Eds.; Biological Nitrogen Fixation and Beneficial Plant-Microbe Interaction; Springer: Cham, Switzerland, 2016; pp. 155-170.

116. Beltrán-García, M.J.; Manzo-Sanchez, G.; Guzmán-González, S.; Arias-Castro, C.; Rodríguez-Mendiola, M.; Avila-Miranda, M.; Ogura, T. Oxidative stress response of Mycosphaerella fijiensis, the causal agent of black leaf streak disease in banana plants, to hydrogen peroxide and paraquat. Can. J. Microbiol. 2009, 55, 887-894. [CrossRef]

117. Beltran-Garcia, M.J.; Martinez-Rodriguez, A.; Macedo-Raygoza, G.M.; Ortiz-Mendoza, D.; Martinez-Molina, C.; VillalobosSantana, G. Cepas Bacterianas, Mezcla Probiótica, Nutriente y Método Para la Producción Agrícola. Patent Pending Application PCT/Mx2021/000006 and MX/a/2021/002192, 26 February 2021.

118. Lima, A.S.; Prieto, K.R.; Santos, C.S.; Paula-Valerio, H.; Garcia-Ochoa, E.Y.; Huerta-Robles, A.; Beltran-Garcia, M.J.; Di Mascio, P.; Bertotti, M. In-vivo electrochemical monitoring of $\mathrm{H}_{2} \mathrm{O}_{2}$ production induced by root-inoculated endophytic bacteria in Agave tequilana leaves. Biosens. Bioelectron. 2018, 99, 108-114. [CrossRef]

119. Costa-Júnior, P.S.P.; Cardoso, F.P.; Martins, A.D.; Teixeira-Buttrós, V.H.; Pasqual, M.; Dias, D.R.; Schwan, R.F.; Dória, J. Endophytic bacteria of garlic roots promote growth of micropropagated meristems. Microbiol Res. 2020, 241, 126585. [CrossRef] [PubMed]

120. Shastry, R.; Welch, M.; Ravishankar, R.; Ghate, S.; Sandeep, K.; Pd, R. The whole-genome sequence analysis of Enterobacter cloacae strain Ghats1: Insights into endophytic lifestyle-associated genomic adaptations. Arch. Microbiol. 2020, 202, 1571-1579. [CrossRef]

121. Paungfoo-Lonhienne, C.; Rentsch, D.; Robatzek, S.; Webb, R.I.; Sagulenko, E.; Näsholm, T.; Schmidt, S.; Lonhienne, T.G. Turning the table: Plants consume microbes as a source of nutrients. PLoS ONE 2010, 5, e11915. [CrossRef] [PubMed] 